Canadian University Music Review

Canadian University Music Review

Revue de musique des universités canadiennes

\title{
Ida Halpern: A Post-Colonial Portrait of a Canadian Pioneer Ethnomusicologist
}

\section{Kenneth Chen}

Volume 16, numéro 1, 1995

Voices of Women: Essays in Honour of Violet Archer

Voix de femmes : mélanges offerts à Violet Archer

URI : https://id.erudit.org/iderudit/1014415ar

DOI : https://doi.org/10.7202/1014415ar

Aller au sommaire du numéro

\section{Éditeur(s)}

Canadian University Music Society / Société de musique des universités canadiennes

\section{ISSN}

0710-0353 (imprimé)

2291-2436 (numérique)

Découvrir la revue

Citer cet article

Chen, K. (1995). Ida Halpern: A Post-Colonial Portrait of a Canadian Pioneer Ethnomusicologist. Canadian University Music Review / Revue de musique des universités canadiennes, 16(1), 41-59. https://doi.org/10.7202/1014415ar

\section{Résumé de l'article}

The work of Ida Halpern (1910-87), one of Canada's first musicologists and a pioneer ethnomusicologist, has been largely ignored. This essay illuminates her most important contribution to the musical development of this country: the documentation of Native musics. Halpern devoted some four decades to recording and analyzing over five hundred songs of the Kwakwaka'wakw, the Nuuchahnulth, the Haida, the Nuxalk, and the Coast Salish First Nations of British Columbia - a truly remarkable achievement considering that a large part of her fieldwork was conducted during a period when it was illegal for Native cultures to be celebrated, much less preserved. The author discusses the strengths and weaknesses of her methodology as well as some factors affecting the reception of her work by academic peers and by the communities she worked with. While Halpern did not always thoroughly investigate context, she endeavoured to write heteroglossically and to invent a theory that accounted for the music of these songs.
All Rights Reserved @ Canadian University Music Society / Société de musique des universités canadiennes, 1995
Ce document est protégé par la loi sur le droit d'auteur. L’utilisation des services d'Érudit (y compris la reproduction) est assujettie à sa politique d'utilisation que vous pouvez consulter en ligne.

https://apropos.erudit.org/fr/usagers/politique-dutilisation/ 


\section{IDA HALPERN: A POST-COLONIAL PORTRAIT OF A CANADIAN PIONEER ETHNOMUSICOLOGIST}

\section{Kenneth Chen}

In an emerging history of music scholars in Canada, Ida Halpern (1910-87) figures paradoxically as a high-profile yet virtually invisible ethnomusicologist of First Nations British Columbian musics. ${ }^{1}$ Her research derived from, but only partially resembles, an Austro-German school of comparative musicology incompatible with the research praxes of North American ethnomusicology, anthropology, and folklore-a clash of four paradigms, which left her unduly ostracized. Her approach furthermore contravenes certain canonic precepts of First Nations Peoples, voices of primary authority whose calls for accountability differ from those practiced traditionally by scholars. An historical visualization of her "voice" is consequently modulated not only by what she might have "said" - the contents of her life's work-but also by frames of reception or means through which her scholarship was, and continues to be, largely set, filtered, and received.

\section{Halpern in Canadian Music History}

Ida Halpern is to date scarcely accounted for in standard textbooks of Canadian music history. This is not surprising insofar as music scholars themselves are rarely the subjects of historical documentation. Reflexive music history, defined by Neuman ${ }^{2}$ as "the history of music history [in which t] he authors of such histories are also, in an extended sense, its subjects," is still a recent development in musicology. Older texts such as Music in Canada, 1600-1800 and A History of Music in Canada, 1534-19144 moreover pre-date Halpern's major debut as a scholar of First Nations musics by some seven and two years, respectively; her absences here are for this reason understandable. In other monographs such as Canadian Music of the Twentieth Century, ${ }^{5}$ which primarily documents the

1 An early version of this paper was read at the annual meeting of the Canadian University Music Society in Charlottetown, Prince Edward Island, June 1992.

2Daniel M. Neuman, "Epilogue: Paradigms and Stories," in Ethnomusicology and Modern Music History, ed. Stephen Blum, Philip V. Bohlman, and D.M. Neuman (Urbana: University of Illinois Press, 1991), 269. An example that particularly complements the contents of this article is Beverley Diamond, "Narratives in Canadian Music History," in Canadian Music: Issues of Hegemony and Identity, ed. Beverley Diamond and Robert Witmer (Toronto: Canadian Scholars Press, 1994).

3 Willy Amtmann, Music in Canada, 1600-1800 (Montreal: Habitex, 1975).

4Helmut Kallmann, A History of Music in Canada, 1534-1914 (Toronto: University of Toronto Press, 1960).

5 George A. Proctor, Canadian Music of the Twentieth Century (Toronto: University of Toronto 
developments of Euro-Canadian art music, she is excluded from consideration by design. The Music of Canada devotes an entire chapter to describing the "Music of the Original Canadians," but as its sub-section on the "Pacific Coast" is poorly referenced, she appears buried in the appendix under a discography of First Nations musics only. ${ }^{6}$

Of three textbooks that actually include Halpern within their discourse, Canada's Music: An Historical Survey merely mentions her once in passing: "other collectors of aboriginal music included Laura Bolton and Ida Halpern."7 The "most substantial" textbook description of her ethnomusicological activities is a 108-word summary written by Peacock in Aspects of Music in Canada, an anthology edited by Walter. ${ }^{8} \mathrm{~A}$ different aspect of her musical life, namely, her championship of Western art music in and around Vancouver, is scatteredly detailed in seven sentences (176 words) within the History of Music in British Columbia, 1850-1950.9

With regard to sources other than Canadian music-history textbooks, in the Encyclopedia of Music in Canada, she is briefly noted in two articles. ${ }^{10}$ Under "Ethnomusicology," her scholarship on Nuuchahnulth [Nootka] and Haida musics is summarized in an excerpt of 130 words. ${ }^{11}$ A 530-word entry by Charles E. Borden constitutes the most comprehensive synopsis to date of her professional accomplishments. ${ }^{12}$ In Ethnomusicology: Historical and Regional Studies, an anthology edited by Myers, Halpern's place in and contribution to ethnomusicology is fleetingly commented upon by Schneider and by Myers, respectively. ${ }^{13}$ Various anecdotes and insights from a personal angle are provided in a magazine interview by Cameron, who as a child took piano-lessons from Halpern, and whose parents knew the Halperns well. ${ }^{14}$ An education booklet by Buchanan and Davies sketches "The Ida Halpern Story," offering information derived from Halpern. ${ }^{15}$ Seven obituaries, in-

Press, 1980). The biases of this vantage-point, including Eastern regionalism and Anglo-Franco hegemony, have been critiqued by Diamond, "Narratives in Canadian Music History."

6Timothy J. McGee, The Music of Canada (New York: W. W. Norton, 1985).

7Clifford Ford, Canada's Music: An Historical Survey (Agincourt: GLC Publishers Limited, 1982), 142.

8 Kenneth Peacock, "Folk and Aboriginal Music," in Aspects of Music in Canada, ed. Arnold Walter (Toronto: University of Toronto Press, 1969), 62-89.

9Dale McIntosh, History of Music in British Columbia, 1850-1950 (Victoria: Sono Nis Press, 1989):

183-84, 211, 213.

10Helmut Kallmann, "Musicology," and Anton Kolstee, "Native North Americans in Canada: 2. Northwest Coast," in Encyclopedia of Music in Canada, 2nd ed., ed. Helmut Kallmann and Gilles Potvin (Toronto: University of Toronto Press, 1992), 909-13, 923-26.

11 Beverley Diamond Cavanagh and James Robbins, "Ethnomusicology," in Encyclopedia of Music in Canada, 2nd ed., 422-31.

12Charles E. Borden, "Halpern, Ida," in Encyclopedia of Music in Canada, 2nd ed., 571.

13 Albrecht Schneider, "Northern and Western Europe. 1. Germany and Austria," in Ethnomusicology: Historical and Regional Studies, ed. Helen Myers (New York: W. W. Norton, 1993): 77-96; Helen Myers, "North American. 1: Native American Music," ibid., 404-18.

14Silver Donald Cameron, "The Collector: And the Music That Nearly Died Lives On," in Weekend Magazine 25, no. 49 (6 December 1975): 16-20.

15 Joan Buchanan and Sandra Davies, "The Ida Halpern Story," in Music in Our Lives-The Pacific Northwest Coast Indians: Music, Instruments, Legends (Vancouver: Western Education Development 
cluding those by Lieberman and Thomas, conclude the set of identified writings on her. ${ }^{16}$

A composite portrait of Halpern, gleaned from the aforementioned published sources, identifies her as a Viennese musicologist who immigrated to Canada with her husband in 1939, a year following the annexation of Austria by Nazi Germany. The first female scholar in the country to hold a doctoral degree in musicology, she was apparently also one of the first scholars, male or female, to do so: "Ida Halpern and Ulrich Leupold, from Vienna and Berlin, respectively, arrived in Canada in 1939, the first with $\mathrm{PhD}$ degrees in musicology in the country." 17 Kallmann offers no indication of who came first. ${ }^{18}$ Cameron writes that Halpern was first but provides no precise dates or explanation to substantiate his claim. ${ }^{19}$

Halpern was distinguished as a musical leader in Vancouver, where she resided. In her role as a music patron, she co-founded The Friends of Chamber Music in 1948, serving as its first president until 1952, its program chair from 1951 to 1958 , and its honorary president from 1952 to 1987 . She began directing the Metropolitan Opera auditions for Western Canada in 1958, presided over the Vancouver Woman's Musical Club from 1960 to 1962, and was named honorary life president of the New Artists' Association. No dates for her honorary appointment are provided by either Borden or McIntosh, the two sources of this information. ${ }^{20}$ The duration of her involvement with the Metropolitan Opera is also unspecified. ${ }^{21}$ In its obituary column, the Central Opera Service Bulletin notes simply that Halpern had served for "a number of years." 22

As a music educator, Halpern taught piano at her home and was a sessional lecturer at the University of British Columbia for more than two decades. She pioneered UBC's first music appreciation course in 1940 and its first ethnomusicology course in 1964. She wrote music reviews for the Vancouver Province from 1952 to 1961, broadcast on Canadian as well as British, German, and Austrian radio and television networks, chaired the seminal Centennial Workshop on Ethnomusicology at UBC in 1967,23 and served as vice-chair of the Community Music School of Greater Vancouver from 1968 to 1972.

Group, 1981), 1. Information derived from Ida Halpern, Indian Music of the Pacific Northwest Coast, Folkways Records Album no. FE 4523, Double-LP, 36 pp. (New York: Folkways Records \& Services, 1967).

16Frederic Lieberman, "In Memoriam: Ida Halpern (1910-1987)," Ethnomusicology 31, no. 3 (1987): 537-38; Phil Thomas, "Ida Halpern-An Excellent Album to Complete a Career," in Canadian Folk Music Bulletin 21, no. 2 (1987): 25.

17 Kallmann, "Musicology," 912.

18Kallmann, "Leupold, Ulrich," in Encyclopedia of Music in Canada, 2nd ed., 748; "Musicology," ibid., 912.

19Cameron, "The Collector: And the Music That Nearly Died Lives On," 16.

20Borden, "Halpern, Ida," and McIntosh, History of Music in British Columbia, 1850-1950, 184.

21 Borden, "Halpern, Ida."

22 Central Opera Service Bulletin 27, no. 4 (1987): 77.

23 Peter Crossley-Holland, Proceedings of the Centennial Workshop on Ethnomusicology, ed. Peter Crossley-Holland (Victoria: Queen's Printer-Gov't. of the Province of B.C., 1968), 1:7, called this Workshop "the first of its kind" in comparing West Coast First Nations musics with the indigenous musics of other cultures elsewhere. A continued interest in the Workshop resulted in four printings of its 
In her capacity as a music scholar, Halpern documented the musics of the Kwakwaka'wakw [Kwakiutl], the Nuuchahnulth [Nootka], the Haida, the Nuxalk [Bella Coola], and the Coast Salish for over four decades, ${ }^{24}$ recording extensive interviews with the musicians, and collecting in excess of 500 songs. As a private collector, Halpern funded her research personally in addition to receiving grants from the Provincial Government of British Columbia in 1977 and the Social Sciences and Humanities Research Council of Canada in 1979. She chaired the research committee of the Canadian Folk Music Society from 1968 to 1972, served as the Canadian delegate to the International Folk Music Council in Ghana in 1966, was a consultant to the United Nations' Habitat Conference in 1976, and identified herself as an elected councellor of the Society for Ethnomusicology and an elected member of the Austrian Society for Musicology. ${ }^{25}$

Halpern was publicly recognized for her life achievements when, in 1956, she was made a founding convocation member of the Simon Fraser University and an honorary associate of its Centre for Communication and the Arts. In 1978, she was awarded an honorary doctorate by SFU and was also named a Member of the Order of Canada. She received a second honorary doctorate from the University of Victoria in 1986.

\section{A Context for Appreciation}

There is a consensus in the scant writings on Halpern that her documentation of First Nations musics was by far her most important contribution to the musical developments of this country. ${ }^{26}$ This accolade is certainly justified on the grounds of technical merit alone, in view of the numerous challenges facing her, literally from the outset.

When Ida Halpern arrived at the Canadian immigration offices in Vancouver in 1939 and was asked what she would do in Canada, she replied that she would collect Indian music. "The immigration officer just laughed and said, well, you will have to think of something better than that. ..." [In] those days the Indians were simply

Proceedings: the 1st ed. in 1968 (called vol. 1 in retrospect); the 2nd ed., a reprint, in 1970 (vol. 1); the 3rd rev. ed. in 1975 (vol. 1); and vol. 2 in 1978.

24 Kolstee, in "Native North Americans in Canada: 2. Northwest Coast," 923, explains the need for scholars now to reference British Columbian Natives by their indigenous names and First Nations status. $\mathrm{He}$ also sums up Halpern's collection as "approximately 350 songs from the Kwakwaka'wakw, the Nuuchahnulth, and the Haida" (ibid., 924), a tally which is presumably partial since it contradicts Halpern's quantification of her own collection at "over 500 songs" (Halpern, Kwakiutl Indian Music of the Pacific Northwest, 2). The figure is also cited by both Borden, "Halpern, Ida," and Lieberman, "In Memoriam: Ida Halpern (1910-1987)." Halpern wrote that her taped "open-ended converstions with the Native songmakers and performer ... amount[ed] to several hundred pages of information" in Kwakiutl Indian Music of the Pacific Northwest.

25Ida Halpern, Haida Indian Music of the Pacific Northwest, Folkways Records Album no. FE 4119, Double-LP, 14 pp. (New York: Folkways Records \& Services, 1986), 1.

26McIntosh, History of Music in British Columbia, 1850-1950, 183-84; Borden, "Halpern, Ida". See also Lieberman, "In Memoriam: Ida Halpern (1910-1987); Cameron, "The Collector: And the Music That Nearly Died Lives On"; Thomas, "Ida Halpern-An Excellent Album to Complete a Career." 
regarded as drunken, lazy and primitive ... [and] "people couldn't have any appreciation that the Indian has a culture." 27

Halpern began and conducted much of her fieldwork during a period when it was actually illegal for First Nations cultures to be celebrated, much less preserved. From 1880 until 1951, the Indian Act forbade First Nations Peoples to partake of their own cultural activities, and Section 140(1) of its 1927 version specifically decreed that: "Every Indian or other person who engages in, assists in celebrating or encourages either directly or indirectly another to celebrate any Indian festival, dance or other ceremony ... is guilty of an offence and is liable on summary conviction to imprisonment for a term not exceeding six months and not less than two months." ${ }^{28}$ Halpern herself acknowledged: "all of us could have been jailed and fined because of strict Canadian laws proscribing native culture at that time."29

Institutionally, the Department of Indian Affairs, the Board of Education as well as the Church enforced a policy of cultural assimilation professedly with the honourable intention of "saving the Indians" by "civilizing" them ${ }^{30}$ - $a$ la Western standards of civilization. But from a First Nations perspective, this forced cultural assimilation was tantamount to cultural genocide. ${ }^{31}$ First Nations Peoples, moreover, had historically been wary of the Europeans ever since initial contact between them had brought about smallpox, measles, influenza, confinement on reservations, poverty, alcoholism, and death. Halpern ${ }^{32}$ reported drastic plunges in their West Coast population from approximately 70,000 in 1835 to 22,605 in 1929 , a loss of nearly $70 \%$ in under a century. ${ }^{33}$

If history prompted the First Nations Peoples to suspect this "white" woman who appeared uninvited at their remote reservations and asked to record their songs, ${ }^{34}$ their distrust was compounded by the tradition that a song was, and still is, regarded as a form of hereditary wealth with prestige, rank, and strict rules governing its ownership, performance, and use. ${ }^{35}$ Many songs were additionally

27Cameron, "The Collector-And the Music That Nearly Died Lives On," 16.

28Reported in Chief Joe Mathias and Gary R. Yabsley, "Conspiracy of Legislation: The Suppression of Indian Rights in Canada," in In Celebration of Our Survival: The First Nations of British Columbia, ed. Doreen Jansen and Cheryl Brooks (Vancouver: UBC Press, 1991), 36-37.

29Halpern, "Nootka Music: Reply to Goodman," Ethnomusicology 25, no. 1 (1981): 294.

30Nurse B. J. [Bessie Jane] Banfill, With the Indians of the Pacific (London: William Kimber, 1966), 175-76.

31 For a significant First Nations articulation of this perspective, see Doreen Jensen and Cheryl Brooks, ed., In Celebration of Our Survival: The First Nations of British Columbia.

32Halpern, Kwakiutl Indian Music of the Pacific Northwest, 3.

33Halpern provided no reference for her statistics, which match exactly the figures derived by Wilson Duff, The Impact of the White Man, Anthropology in British Columbia, Memoir, no. 5; The Indian History of British Columbia, vol. 1, 2nd ed. (Victoria: Provincial Museum of Natural History and Anthropology, 1969; reprinted 1980), 39.

34 In "Narratives in Canadian Music History," 149-50, Diamond suggests that relatively little consideration has been given to ethnicity as a factor affecting musical scholarship: she points to the poor representation of ethnic minorities in Canadian music history textbooks as stemming in part from an Anglo-Franco hegemony. Halpern's case adds to this view by showing that a converse scenario, being "white," may not be ipso facto advantageous either.

35Halpern, Kwakiutl Indian Music of the Pacific Northwest, 5. 
shrouded in secrecy to protect not only their sacred contents and their performative powers but also the uninitiated person from the dire consequences of encountering such songs inappropriately. ${ }^{36} \mathrm{Her}$ request thus ran counter to spiritually-founded, intricate socio-cultural rules, and she subsequently had to spend six years earning the trust of Chiefs and Elders before they would even grant her access to their traditional repertoires: "I started to collect Indian folk music as soon as I entered Canada in 1939. However, it took six years of intensive contact-making before I was successful in convincing the Indians that they should sing for me their old authentic songs." 37

Her early audio-recording equipment was bulky, cumbersome to use, and difficult to transport. ${ }^{38}$ She conducted much of her fieldwork by herself, and in all likelihood, her lone travels to and from the reservations would have been rendered frequently challenging, perilous, or even impossible at times by the quick-changing weather, the unpaved backcountry roads, and the use of ferries. Her recording conditions were also rarely ideal:

Six or eight drummers sit in a semicircle and the singers, Frank Williams and some women, dance gracefully, taking small steps. ... [In this] Quiquatla dance ... [t]he drums beat steadily. The dancers float. In the background of this large field in Port Alberni, ... [located amid] the rain forest of Vancouver Island, ... dogs bark and children play. And a woman, a white woman, manipulates a primitive tape recorder connected to its power source by yards of umbilical extension cord. She knows nothing about recording, but she senses the drums will be too loud. She strains to raise the microphone nearer the singers, away from the insistent drums. ${ }^{39}$

In his review of her second record album, Indian Music of the Pacific Northwest Coast, Evans noted that "some of the tracks display recording level fluctuations, abrupt starts in the middle of a note, and poor microphone placement." 40 A similar assessment was reached by Goodman in her review of the same album. ${ }^{41}$ Yet on other occasions, Halpern apparently succeeded in making field recordings that were, according to Gunther, who reviewed the first record album (Indian Music of the Pacific Northwest Coast):

very good ... in contrast to many less-successful attempts at collecting such music by scholars in the field. Usually in the Indian house, with interruptions, background

36Halpern, "Music of the BC Northwest Coast Indians," Proceedings of the Centennial Workshop on Ethnomusicology, ed. Peter Crossley-Holland (Victoria: Queen's Printer-Gov't. of the Province of B.C., 1968), vol. 1 [Workshop Proceedings], 23-42, and vol. 2, The Complete Discussions, 20-34, 79; idem, "On the Interpretation of 'Meaningless-Nonsensical Syllables' in the Music of the Pacific Northwest Indians," Ethnomusicology 20, no. 2 (1976): 253-71.

37Halpern, Indian Music of the Pacific Northwest Coast, 2.

38Lieberman, "In Memoriam: Ida Halpern (1910-1987)", 538.

39 Cameron, "The Collector: And the Music That Nearly Died Lives On," 16.

40David Evans, "Record Reviews: North American Music," Journal of American Folklore 90, no. 358 (1977): 368.

41 Linda J. Goodman, record review of Ida Halpern's Nootka: Indian Music of the Pacific Northwest Coast, Folkways Album no. FE 4524 (New York: Folkways Records \& Services, 1974) in Ethnomusicology 25, no. 1 (1981): 162-65. 
noise, nervous singers and uncertain portable equipment, the results are not of top quality. None of these difficulties are apparent in this album. ${ }^{42}$

In view of the technical, technological, physical, sociocultural, historical, institutional, legal, attitudinal, and many other challenges she had to overcome in her fieldwork, ${ }^{43}$ Halpern's feat of recording of "one of most extensive and valuable collections" 44 on the First Nations musics of this region is surely remarkable.

\section{Estranged Receptions}

The tributes paid to Halpern, however, ring hollow beside the somber observation that, in reality, her scholarship on First Nations musics has largely been overlooked by ethnomusicologists, anthropologists, and folklorists. Halpern is rarely if at all cited in the bibliographies or discographies of context-oriented studies on the Kwakwaka'wakw, the Nuuchahnulth, the Haida, the Nuxalk, and the Coast Salish. ${ }^{45}$ The actual incorporation of her work by others is rarer still. ${ }^{46}$ A recent Encyclopedia of Music in Canada survey of research conducted on First Nations musics of the Northwest Coast ${ }^{47}$ does not even list her tour de force documentation of Kwakwaka'wakw music, Kwakiutl Indian Music of the Pacific Northwest, a puzzling omission since,

despite an abundance of ethnographic attention, recordings of [Kwakwaka'wakw] music - both published and privately held—are very rare. ... Ida Halpern has had

42Ema Gunther, record review of Ida Halpern's Nootka: Indian Music of the Pacific Northwest Coast, Folkways Album no. FE 4524 (New York: Folkways Records \& Services, 1974) in Ethnomusicology 25, no. 1 (1970): 524.

43The non-consideration here of gender, central to this Festschrift, is unfortunate, somewhat ironic, but unplanned as this essay was written originally to serve a different purpose. Recent studies on gender and ethnomusicological fieldwork include Marcia Herndon and Susanne Ziegler, ed., The World of Music: Women in Music and Music Research 33, no. 2 (1991); Ellen Koskoff ed., Women and Music in Cross-Cultural Perspective (New York: Greenwood Press, 1987); and more anthropologically, Tony Larry Whitehead and Mary Ellen Conoway, ed., Self, Sex and Gender in Cross-Cultural Fieldwork (Urbana: University of Illinois Press, 1986). Calls specifically to inter-relate gender with the politics and/or economics of class and of ethnicity have also been urged notably by Susan McClary, "Towards a Feminist Criticism of Music," Canadian University Music Review, no. 10/2 (1990): 9-18; Diamond, "Narratives in Canadian Music History"; Ruth Solie, ed., Musicology and Difference: Gender and Sexuality in Music Scholarship (Berkeley: University of California Press, 1993).

44Cavanagh and Robbins, "Ethnomusicology," 425.

45See for example, Stanley Walens, Feasting with Cannibals: An Essay on Kwakiutl Cosmology (Princeton: Princeton University Press, 1981); Margaret B. Blackman, During My Time: Florence Edenshaw Davidson, a Haida Woman (Seattle: University of Washington Press, 1982); Marianne Boelscher, The Curtain Within: Haida Social and Mythical Discourse (Vancouver: University of British Columbia Press, 1988); Wendy Bross Stuart, Gambling Music of the Coast Salish Indians, Ethnology Division Paper, no. 3 (Ottawa: National Museum of Man, and National Museums of Canada, 1972); Pamela Amoss, Coast Salish Spirit Dancing: The Survival of an Ancestral Religion (Seattle: University of Washington Press, 1978).

46Kathleen E. Bowles, An Ahouset Elder's Songs: Transcription and Analysis, unpublished M.A. thesis (Vancouver: University of British Columbia, 1991); Marius Barbeau and Alan Lomax, comp. and ed., World Library of Folk and Primitive Music. Volume VIII: Canada, Columbia Record no. SL 211 (New York: Columbia Records, 1953).

47Kolstee, "Native North Americans in Canada: 2. Northwest Coast," 923-26. 
the unusual, and enviable, opportunity to engage in field research over several decades ... and to produce recordings with considerable time-depth. ${ }^{48}$

It may be that Halpern's colleagues were unfamiliar with the full extent of her scholarship, a covert factor that may partially explain the enigma of her exclusion. On the one hand, a literature search revealed fourteen publications by her over a period of some four decades (see the Appendix for a comprehensive list)-fifteen (and nearly five decades) if her unpublished Ph.D. dissertation is included $\mathrm{d}^{49}$-and thus she appears at a first glance to have published somewhat regularly over the years, even if not prolifically. ${ }^{50}$ But on the other hand, this perception is deceptive since she presented the bulk of her research findings in essentially six publications, four of which-her core writings-also happen to be liner-notes of long-playing record albums, ${ }^{51}$ the fifth (1978) is a non-music, non-academic publication of the Provincial Archives of British Columbia, and only the sixth (1976) is an article in a "regular"-ethnomusicology-journal. Against the established scholarly communication network of academic journals, anthologies, and monographs-liner-notes being regarded overall as a medium of written information that is more supplemental than on par with the others despite sound recordings having always played a central role in ethnomusicology-it is easy to see how her off-the-beaten-track writings may have been intentionally or unintentionally missed.

On the flip side, a greater or sole exposure to Halpern's "mainstream" publications is also apt to promote a skewed understanding of what her scholarship was really about. In the first decade of her life as a music scholar, she produced a doctoral dissertation on the critical reviews of Franz Schubert as well as an article on appreciating twentieth-century Euro-Western art music, thus imparting to her readers a sense of her musicological training in Western art music. ${ }^{52}$ Over the next three decades, a two-page summary of a paper on Kwakwaka'wakw music which she had presented to the 14th Annual Confer-

48Marcia Herndon, record review of Ida Halpern's Kwakiutl Indian Music of the Pacific Northwest, Folkways Records Album no. FE 4122 (New York: Folkways Records \& Services, 1981), Ethnomusicology 29, no. 3 (1985): 540.

49 Halpern, Franz Schubert in der zeitgenössischen Kritik, unpublished Ph.D. dissertation (University of Vienna, 1938).

50Halpern's 1953 publication-"Bella Bella and Kwakiutl Songs," in World Library of Folk and Primitive Music. Volume VIII: Canada, comp. and ed. Marius Barbeau and Alan Lomax, Columbia Record no. SL 211 (New York: Columbia Records, 1953)-comprises a brief 140-word annotation to 3 (out of 39) musical selections she had recorded on a compilation recording of Canadian traditional musics- too brief to be considered here. Her 1978 publication - ““... a very agreeable harmony': Impressions of Nootkan Music," in Sound Heritage 7, no. 1 (1978): 63-70-is co-authored with her research assistant David Duke.

51 Halpern's wrote liner notes for the following long-playing records: Indian Music of the Pacific Northwest Coast (1967), Nootka Indian Music of the Pacific Northwest Coast (1974), Kwakiutl Indian Music of the Pacific Northwest (1981), Haida Indian Music of the Pacific Northwest (1986). Halpern's other major publications are: ““... a very agreeable harmony': Impressions of Nootkan Music,” with David Duke and "On the Interpretation of 'Meaningless-Nonsensical Syllables' in the Music of the Pacific Northwest Indians."

52Halpern, Franz Schubert in der zeitgenössischen Kritik; "What is Modern Music?" Pacific Northwest Library Association Quarterly 11, no. 2 (1947): 70-75. 
ence of the International Folk Music Council, ${ }^{53}$ an article on "Music of the B.C. Northwest Coast Indians" 54 that is derived-verbatim in many sections-from her 1967 liner-notes, an article in Ethnomusicology on interpreting vocables, ${ }^{55}$ a book review, ${ }^{56}$ a survey article on West Coast First Nations musics written for the first edition of the Encyclopedia of Music in Canada ${ }^{57}$ and two letters to the editor of Ethnomusicology ${ }^{58}$ protesting an unfavorable review of her 1974 record album in that journal offer the impression that she pursued six synchronically-approached goals in First Nations musical research: recording traditional songs; profiling singers' recollections of traditional performance contexts in which these songs functioned; transcribing and interpreting descriptively the melodies, percussion accompaniments (if present) and texts of the songs; taxonomizing the song genres according to musical stylistic features in addition to song function; inferring a Pacific Northwest Coast-hence "regional"-musical idiom; and comparing such idiomatic as well as stylistic features crossculturally.

But what Halpern's "mainstream" publications do not reflect are her growing shifts away from synchronic documentations to more diachronic approaches, from conducting research oriented at cross-cultural comparisons to comparative investigations concentrated within single cultures, from static taxonomy to problem-solving research, and from always having profiled the explanations of her singers in the foreground to giving them an even greater prominence in "tell[ing] their own story." 59 These shifts are manifested in the liner-notes of her last decade of scholarship ${ }^{60}$-albeit conflictingly at first as polar types of analyses are presented within the same document.

In the extended early phase of her scholarship, Halpern pursued a classification of what were to her "the oldest"-but otherwise historically-undifferentiated-examples of "authentic" Kwakwaka'wakw and Nuuchahnulth songs. ${ }^{61}$ She inventoried their stylistic and idiomatic features both compositionally (intervallic relations, melodic motion, phrasing, texture, rhythmic modes, musical form as well as compositional principles of repetition, variation, and contrast) and in terms of vocal production (from timbre of voice to performance practices), identifying cumulatively twenty-three features in her 1967 liner-

53Halpern, "Kwa-kiutl Indian Music," Journal of the International Folk Music Council 14 (January 1962): 159-60.

54 "Music of the BC Northwest Coast Indians," in Proceedings of the Centennial Workshop on Ethnomusicology (1968).

55 "On the Interpretation of 'Meaningless-Nonsensical Syllables' in the Music of the Pacific Northwest Indians".

56Review of Pamela Amoss' Coast Salish Spirit Dancing: The Survival of an Ancestral Religion (Seattle: University of Washington Press, 1978), Ethnomusicology 24, no. 2 (1980): 287-89.

57 "Indians" and "Pacific Northwest Coast," in Encyclopedia of Music in Canada, ed. Helmut Kallmann, Gilles Potvin, and Kenneth Winters (Toronto: University of Toronto Press, 1981), 448-50.

58 "Nootka Music: Reply to Goodman," Ethnomusicology 25, no. 2 (1981): 294-97; and "Letter to the Editor," Ethnomusicology 27, no. 1 (1983): 171-73.

59Halpern, Haida Indian Music of the Pacific Northwest, 2.

60 Halpern, Kwakiutl Indian Music of the Pacific Northwest (1981); Haida Indian Music of the Pacific Northwest (1986).

61 Halpern, Haida Indian Music of the Pacific Northwest, 2. 
notes and 1968 article, ${ }^{62}$ twenty-five features in her 1974 liner-notes, ${ }^{63}$ and twenty-nine features in her 1981 liner-notes. ${ }^{64}$ She also investigated the onomatopoetic meanings of vocables ${ }^{65}$ and ventured to compare her findings cross-culturally, including noting the similarity of some pentatonic scale formations she had inferred to the pelog system of Javanese music, ${ }^{66}$ associating what she had deemed to be primarily "melogenic"-melody-oriented-songs with "the melogenic style which is the style of our western culture,"67 and speculating on the rare occurrence of polyphonic singing in some Nuuchahnulth songs as evidence of musical acculturation:

It is in [Nuuchahnulth] music that the first attempts at polyphony occur among the Northwest Coast Indians. ... One point to keep in mind is that the [Nuuchahnulths] were the first Indians to be in contact with the white man. (Captain Cook was greeted by the Nootka.) The thought occurs that there might be a coincidence between this long association with the white man and his music and [this] characteristically Western musical element. ${ }^{68}$

On the surface, this phase of Halpern's scholarship appears mostly to instantiate the diffusionist, cultural evolutionist, and comparative views of the BerlinVienna or, simply, Berlin Kulturkreislehre or culture circle school that had dominated anthropology from the mid-1880s until the 1930s, and in ethnomusicology, hegemonically until the 1940s, and peripherally into the 1960s: "the so-called Berlin school ... began with Stumpf and Hornbostel, and consisted of their students such as Herzog, Kolinski, Bose, Wachsmann, along with other scholars connected in one way or another with this group, such as Robert Lach [at Vienna]. ..." 69 Influenced by Darwinist evolutionary theory, this school, according to Schneider, presupposed that humans evolved into existence at a common point of origin, probably Central Asia, from which they subsequently migrated in waves to the rest of the world, and "progressed" at varying rates. ${ }^{70} \mathrm{~A}$ second presupposition of Eurocentric cultural monogenesis-a unilineal progression of human developments pinnacled by the inventions of Euro-Western civilizations-buoyed the examination of cultural artefacts including music and musical

62Halpern, Indian Music of the Pacific Northwest Coast, 7; "Music of the BC Northwest Coast Indians," 25-56.

63 Halpern, Nootka Indian Music of the Pacific Northwest Coast, 23-42.

64Halpern, Kwakiutl Indian Music of the Pacific Northwest, 7.

65Halpern, Nootka Indian Music of the Pacific North West Coast, 3; "On the Interpretation of 'Meaningless-Nonsensical Syllables' in the Music of the Pacific Northwest Indians"; "Indians" and

"Pacific Northwest Coast," 450.

66Halpern, "Kwa-Kiutl Indian Music,"160; and Indian Music of the Pacific Northwest Coast, 6;

"Music of the BC Northwest Coast Indians," 24; "Indians" and "Pacific Northwest Coast," 449.

67 Halpern, Indian Music of the Pacific Northwest Coast, 6; verbatim in "Music of the BC Northwest

Coast Indians," 25; "Indians" and "Pacific Northwest Coast," 450.

68 Halpern, Nootka Indian Music of the Pacific North West Coast, 1.

69 Bruno Nettl, "Western Musical Values and the Character of Ethnomusicology," The World of Music 26, no. 1 (1984): 29.

70Schneider, "Northern and Western Europe. 1: Germany and Austria," 78-79. 
instruments as markers of how primitive or civilized the culture in question was by comparison. In Halpern's own words,

music is subconscious, instinctive, and the true expression of a people, and it illustrates their innermost feeling and make-up. In the process of exchange and assimilation, a people acquires tools, weapons, and implements. But they preserve their ancient songs because singing is a fundamental expression of man and has little to do with the changeable surface of life. This is why music is one of the steadiest elements in the evolution of mankind. ${ }^{71}$

Halpern's espousal of Berlin-school philosophy is not surprising given that she had studied her Ph.D. under Lach as well as Egon Wellesz, ${ }^{72}$ the latter a Byzantine music specialist and co-founder of Monumenta musicae byzantinae who reportedly also "shared ... Lach's interest in Oriental music ... and published on the relations of music of the Near East and Europe."73 In turn, the seeming ease with which these two mentors of hers traversed the musicology-ethnomusicology "border" still in effect at many post-secondary institutions today likely facilitated her concentration on First Nations musical research following her doctorate in Euro-Western art music.

Halpern did, however, do more than instantiate Kulturkreis concepts even in her early scholarship. Notably, in comparing West Coast First Nations and Euro-Western art musics, she reasoned that:

The [former] may be considered melogenic [my emphasis]. Sometimes it is logogenic (world-bound, logos-word) as when the chief sings his potlatch song and recites some parts. Sometimes it can be pathogenic (pathos-full of emotion) as in a medicine man's song. Often, however, it passes these two primitive stages, blending already into the melogenic style which is the style of our western culture. ${ }^{74}$

This argument downplays the "primitive" (logo- and pathogenic) features of First Nations musics in favor of the more "progressive" (melogenic) style found also in Euro-Western art music-a disconcerting move logically insofar as Halpern's inference (underlined) does not flow from what her evidence actually supports. From a phatic point of view, though, her rationale betrays her eagerness to present First Nations music-making as developmentally "like" EuroWestern art music-making: advanced rather than backward. This agenda of hers to elevate the status of the former musics to "heights" comparable with those of the latter is, in my opinion, what differentiates her subtly but significantly from the Berlin school, which sought more to determine the evolution-not equation—of the world's musics eurocentrically. ${ }^{75}$

71 Halpern, "Music of the BC Northwest Coast Indians," 11.

72Halpern, Indian Music of the Pacific Northwest Coast, 1; Nootka Indian Music of the Pacific North West Coast, 1; Kwakiutl Indian Music of the Pacific Northwest, 1; Haida Indian Music of the Pacific Northwest, 1. Less frequently, she named Guido Adler and Robert Haas as her other teachers at the University of Vienna.

73 Schneider, "Northern and Western Europe. 1: Germany and Austria," 83.

74Halpern, Indian Music of the Pacific Northwest Coast, 6; "Music of the BC Northwest Coast Indians," 25; "Indians" and "Pacific Northwest Coast," 450.

75 Halpern's seemingly ad hoc comparison of similarly patterned First Nations and Javanese musical 
Admittedly, as a "product" of this school, Halpern was apparently no less eurocentric in her early attempts at advancing the musics she studied to be as worthy as Euro-Western art music. Yet in doing so, the presupposition of cultural monogenesis also became increasingly untenable for her. Paradigmatically, she resolved this tension by approximating more and more historical particularism, the dominant North American form of cultural polygenesis which eschews eurocentric, evolutionary cross-cultural comparisons in favour of intensive single-culture documentation. Her approximations, however, have been obscured by the gradualness with which they occurred (into the early 1980s), by her continued use of old-school terminology (e.g., melo-, logo-, and pathogenic), by the lingering comparative tint of her writings (intra-cultural when no longer inter-cultural), and by the fact that she never distanced herself from her monogenetic pursuits, recapitulating instead her own research history as one continual design. ${ }^{76}$

From a reception point of view, it is unfortunate that her departure from the Berlin School was not more pronounced. Evans, in reviewing Halpern's first record album, Indian Music of the Pacific Northwest Coast, commented that she wrote in "the style and terminology of early-twentieth-century German ethnomusicology [which] some modern researchers find rather dated."77 Several senior ethnomusicologists have opined in private the same attitude regarding her writings in general-not just her early publications. Such a misperception undoubtedly played a role in eclipsing her more innovative research, which included a diachronic comparison of two performances of a Kwakwaka'wakw Raven song sung by the same singer, Chief Billy Assu, twenty-nine years apart, ${ }^{78}$ and a re-theorizing of Haida musical scales as foundation tones with flexible intervallic relationships to better represent the microtonal inflections and microtonal migrations used in creating intricate variations to otherwise repetitive songs. ${ }^{79}$ Lieberman noted that she was "one of the earliest to call attention to the important role and religious meaning of so-called 'meaningless syllables' [vocables] in native song." 80

In Ethnomusicology, where three of her record albums were reviewed and each deemed to be contextualized unevenly, her documentation is further reputed to be problematic ethnographically. Gunther, an anthropologist, found the 1967 liner-notes to be wanting in details needed for identifying a people and their music cross-culturally:

As with music from other cultures, "program notes" are very important; and here it would seem that a better brochure could have been produced. ... Tribal subgroups are often mentioned casually with no indication of where they are and with names

scales may be seen as another attempt on her part to equate the former musical cultures with the latter, an ancient "high" musical culture.

76 This is especially evident in Kwakiutl Indian Music of the Pacific Northwest, 3; "Indians" and "Pacific Northwest Coast"; and Haida Indian Music of the Pacific Northwest.

77Evans, "Record Reviews: North American Indian Music," 366.

78Halpern, Kwakiutl Indian Music of the Pacific Northwest, 17-18.

79Halpern, Haida Indian Music of the Pacific Northwest, 2.

80Lieberman, "In Memoriam: Ida Halpern (1910-1987)," 537. 
spelled in a manner difficult to equate with the standard literature. The map is really startling for there is no outline of Vancouver Island except for some of the shore line on the west coast. ${ }^{81}$

Goodman, another anthropologist, bluntly denounced Halpern for relaying "inadequate and frequently inaccurate ethnographic information" in the 1974 liner-notes; for crediting song-owners improperly and thereby "do[ing] them a great disservice"; for quoting sources far too "brief[ly, and] out-of-context); for explaining Nuuchahnulth terms and events "incompletely," "misleadingly," or "incorrectly"; for misapplying the anthropological concepts of moiety and matrilineage; and for misanalysing the compositional structure of songs to imply "an untenable unilineal evolutionary musical sequence." 82 The ethnomusicologist Herndon, in reviewing Halpern's third set of liner-notes, more diplomatically questioned

whether a better strategy might not have been for her to expand slightly the extensive notes and transcriptions into a book accompanied by the recordings. The booklet included in the inside pocket of [this] album should not be called "descriptive notes," since they actually constitute a mini-monograph. In their present form, these comments and transcriptions are very helpful, but leave the reader/hearer wanting more. $^{83}$

Particularly in her 1967 and 1974 liner-notes, Halpern rarely referenced her primary sources or even used quotation marks to set apart what they said. Goodman's assessment of the 1974 notes as ethnographically inadequate is therefore justified. Goodman's conclusion, however, that Halpern had performed "a great disservice" to her singers by not crediting them properly is, in view of the mini-biographies also provided to introduce each singer individually, excessive. ${ }^{84}$ As for other criticisms, certain changes in her subsequent writings suggest that she herself accepted as valid some of the charges levied against her. She reacted to Gunther's criticism of an incomplete map in the 1967 liner-notes with two maps-one comprehensive and the other an enlargementin the 1974 set. ${ }^{85}$ In her 1981 "mini-monograph," she mentioned for the first time her post-graduate training in anthropology under the noted scholar Diamond Jenness as if to reinforce the credibility of her own fieldwork. ${ }^{86}$ Some photographs of singers also appeared in this publication following Goodman's comment previously about their absence, as did more and lengthier quotations

81 Erna Gunther, record review of Ida Halpern's Nootka: Indian Music of the Pacific Northwest Coast, Folkways Album no. FE 4524 (New York: Folkways Records \& Services, 1974) in Ethnomusicology 25, no. 1 (1970): 525.

82Goodman, record review of Ida Halpern's Nootka: Indian Music of the Pacific Northwest Coast, 163-65.

83Herndon, record review of Ida Halpern's Kwakiutl Indian Music of the Pacific Northwest, 540.

84Halpern, Indian Music of the Pacific Northwest Coast, 2-5; Nootka Indian Music of the Pacific North West Coast, 4-5; Kwakiutl Indian Music of the Pacific Northwest Coast, 13-14; Haida Music of the Pacific Northwest, 10-14.

85 Halpern, Nootka Indian Music of the Pacific North West Coast, 5.

86Halpern, Kwakiutl Indian Music of the Pacific Northwest, 2. 
which are now carefully indicated with quotation marks in both the 1981 and 1986 liner-notes-Halpern's response to Goodman's charge of "inadequate and frequently inaccurate ethnographic information?"

The said problems aside, Halpern's liner-notes also do not readily resemble familiar forms of ethnographic writings-another factor likely undermining their reception by her peers ${ }^{87}$ As an illustration, her discussion of Kwakwaka'wakw kinship organization, quoted in its entirety below, is typical of the many capsule-dense if not cryptic-explanations of context she provided:

The [Kwakwaka'wakw] were composed of four phratries-Raven, Eagle, Killer Whale and Wolf. They were allowed to marry outside their own phratry. The child belonged to the mother's phratry (matrilineal descent) but could later change to his father's. Human beings dressed in Raven dress but were not considered descendants of the Raven. ${ }^{88}$

Halpern endeavoured in her liner-notes to foreground her "native experts"89 as the primary and proper authorities of their own cultures. She kept "[f]or authenticity's sake the words [and logic] of the informants in the explanations ... as close as possible to their way of expressing themselves [in English]," 90 further clarifying in her 1967 but not 1974 liner-notes that what came "directly from [them] ... were the explanations of songs and meanings."91 This was her understanding and personal practice of an "'Emic' approach," which she defined as "research directly from Native Indians." 92

In turn, drawing on what she considered to be her own strengths, Halpern "transcribed and analysed their music and identified all the characteristics of their Native concepts, integrating them into a format that [was] both logical and understandable to our Western musical tradition." 93 Thus, she not only acknowledged and operated within the limitations of her own expertise in her fieldwork, but she distinctly sought as well to honour the expertise of her singer-elders by according them self-representation within her writings. ${ }^{94}$ Her attempts at not

87 It was probably also to her disadvantage that the "father" of historical particularism, the anthropologist Franz Boas, had previously set a mammoth standard for West Coast First Nations ethnography with his "fabled five-foot shelf of materials on the [Kwakwaka'wakw]" (reported in Arnold Krupat, Ethnocriticism: Ethnography, History, Literature [Berkeley: University of California Press, 1992], 83).

88 Halpern, Indian Music of the Pacific Northwest Coast, 1.

89Halpern, "Nootka Music: Reply to Goodman," 297.

90Halpern, Indian Music of the Pacific Northwest Coast, 2, and repeated verbatim in Nootka Indian Music of the Pacific North West Coast, 2.

91 Halpern, Indian Music of the Pacific Northwest Coast, 2.

92Halpern, Kwakiutl Indian Music of the Pacific Northwest, 3.

93 Ibid.

94 When accused by Goodman of presenting faulty ethnographic information, "the credibility of old chiefs is attacked" became Halpern's rallying cry of defence in both "Nootka Music: Reply to Goodman," Ethnomusicology 25, no. 2 (1981): 294 and "Letter to the Editor," Ethnomusicology 27, no. 1 (1983): 171. Halpern, however, did not make her writing style clear in her 1974 liner-notes, and so Goodman's comments should be read with this consideration in mind. As for the many points of contention between them, the questions of what and who were "wrong" remain to be contextualized. 
voicing-over her "informants" in her scholarship, although flawed, nonetheless anticipate post-modernist calls to write more heteroglossically-a form of ethnographic representation that would not even be significantly considered by anthropologists until the appearance of Clifford's "On Ethnographic Authority" in $1983,{ }^{95}$ and thereafter by ethnomusicologists.

On yet another point of departure, in a handwritten note to the founder of Folkways Records regarding the production of her 1986 album, Halpern revealed the pedagogical orientation of her writing over-narrowly speakingthe communication of ideas with her academic peers:

Dear Mr. [Moses] Asch, I hope you will enjoy my opus. You may see why it took so long. FE 5324 [FE 4523?96] is used for classes [at] many universities, so I wanted to keep the same standard or better. My warmest wishes and best regards, Ida Halpern. ${ }^{97}$

Halpern's agenda to design materials for teaching West Coast First Nations musics at a university-level raises the question of whether her 1967 and 1974 liner-notes may not have been similarly directed as well, and hence it calls into question the appropriateness of reviewing her liner-notes as ethnographies and not as instruction manuals. Since she did not declare this impetus in any of her publications, Gunther, Goodman and Herndon cannot be faulted for what they wrote on this count. Yet one wonders if Halpern's deviation from this "norm" of practices may not have contributed significantly to the weak reception overall of her work in ethnomusicology and in anthropology. Her pedagogical intent, giving rise to largely descriptive and highly technical music transcriptions, ${ }^{98}$ likely jeopardized her standing as well with Canadian folklorists, who tend to favour the production of more assessible performing scores for reaching a broader target-audience. ${ }^{99} \mathrm{Her}$ analytical transcriptions would have been at odds with the latter aim to promote the performance of "folk" and "ethnic" musics in addition to collecting and studying them.

In a biography of the late Kwakwaka'wakw Chief Mungo Martin, "as told by his immediate family ... [and by others]," 100 Halpern is conspicuous by her absence from this insider account of the man who represented, for her fieldwork, one of the key figures and primary sources of both songs and cultural informa-

95 James Clifford, “On Ethnographic Authority," Representations 2 (1983): 132-43.

96 The record label number given by Halpern is most likely a typographical error as FE 5324 is not an album by her, but one of Missouri Folk Songs recorded by Loman D. Cansler. FE 4523, on the other hand, references Halpern's 1981 album.

97 An undated letter in the "Ida Halpern" folder of The Folkways Collection (New York: Folkways Records \& Services, 1986). My thanks to Lori Elaine Taylor of the Folkways Archives, Smithsonian Institution, Washington, D.C., for her assistance in accessing this and several other documents to me.

98These include modified notations, rhythmic modes, diagrams of musical form, and sonograms.

99Edith Fowke, "Collecting and Studying Canadian Folk Songs," in Ethnomusicology in Canada, Proceedings of the the First Conference on Ethnomusicology in Canada, co-sponsored by the Institute for Canadian Music, Faculty of Music, University of Toronto, and the Faculties of Fine Arts and Graduate Studies, York University, ed. Robert Witmer (Toronto: Institute for Canadian Music, 1990), 295-99.

100B.C. Indian Arts Society, Mungo Martin: Man of Two Cultures (Sidney, B.C.: Gray's Publishing, 1982), viii. 
tion. ${ }^{101}$ In his essays on the loss, rebirth, and re-learning of First Nations songs, dances, and cultures, the much-decorated Nuuchahnulth Elder and consummate artist, singęr, dancer, author, and actor George Clutesi, another key figure in Halpern's fieldwork, also does not mention her in his writings. ${ }^{102}$ And in an autobiography of Kwakwaka'wakw Chief Harry Assu, there is only a passing reference to her collaboration with his father, the late Chief Billy Assu:

My father was a very good singer. He sings some of his songs on a record by Ida Halpern. She came up and stayed here in my house for the opening of the Kwagiulth Museum in 1979 and brought me the record [Kwakiutl Indian Music of the Pacific Northwest]. ${ }^{103}$

A First Nations perspective on Halpern's persona non grata standing may be gleaned indirectly from an explanation of a parallel but otherwise unrelated incident by Geraldine Bob; a UBC student of Nle'kepmx ancestry:

For instance, if you look at my mother or my grandmother or other people's grandparents, these are people who don't know how to read. Many of them won't speak English or they speak very little English. Many of them rarely come off the reserves and many of them do not get involved with academic life. [laughter] So I don't know how they got in touch with anthropologists in order to learn how to be Indian. ${ }^{104}$

Bob restores credit to First Nations elders for living and growing with, and not just passing down as isolable bits of knowledge, their cultural and musical traditions-a fact still readily obscured today by Euro-Western paradigms of thought that continue to adhere to the fear if not belief that such traditions are in danger of "vanishing." Encircling the same end, Urion argues profoundly that

First Nations discourse ... [does] not form simply a "data corpus" for academic exposition as ethnohistory. The validity of [its] generalizations ... does not emanate from ethnohistorical cross-validation, butressed by archival sources. That kind of validity is elemental. The validity of the discourse is the moral authority of the interactants to the interviews, who know that the earth witnessed the things about which they spoke. ${ }^{105}$

With the issue of self-determination for First Nations peoples recently at stake, Halpern would likely have been sidestepped less because she contributed nothing significant toward the process than because the need to redress past and

101 Halpern, Kwakiutl Indian Music of the Pacific Northwest (1981); and "Nootka Music: Reply to Goodman" (1981).

102George Clutesi, Stand Tall, My Son (Victoria: Newport Bay Publishers, 1990).

103 Harry Assu, with Joy Inglis, Assu of Cape Mudge: Recollections of a Coastal Indian Chief (Vancouver: University of British Columbia Press, 1989).

104 Cited in Sheila Te Hennepe, "Issues of Respect: Reflections of First Nations Students' Experience in Postsecondary Anthropology Classrooms," Canadian Journal of Native Education 20, no. 2 (1993): 226.

105Carl Urion, "Changing Academic Discourse about First Nations Education: Using Two Pairs of Eyes (Editorial)," Canadian Journal of Native Education 18, no. 1 (1991): 8. 
present realities from a First Nations perspective makes it more pressing to publicly focus instead on First Nations involvements. Indeed, in Kwakiutl Indian Music of the Pacific Northwest (1981), 14, Halpern intimated her personal receipt of a "letter of appreciation" from Don Assu, grandson of the late Chief Billy Assu, "for having preserved the songs of his grandfather, which now means so much to them." But even as the relative positions occupied by academics shift increasingly off-center, her career as a fringe scholar, with its share of triumphs and mistakes, may yet prove beneficial as a concrete foil for reflecting on community-sensitive approaches to First Nations musics in particular, and Canada's multi-cultural musics in general.

\section{Conclusion}

If there is one anecdote which summarizes what was remarkable about Halpern-her tenacious yet seemingly "gentler and kinder" approach-it is, in my opinion, her waiting six years for permission to record a traditional song. Throughout her life's work, she demonstrated repeatedly her ability to persevere against the odds, but rarely if ever by riding roughshod over the people who stood in her way. Friendship above and beyond a professional association was, for her, the cornerstone of her research:

Indian chiefs are not impressed by the social or professional status of white people who come to hear them sing. They will not give the collector their songs unless he can win their complete confidence during years of personal association and by many small tokens of genuine interest and goodwill. ${ }^{106}$

Halpern not only regarded the people with whom she worked as "respected old chiefs," "giants of their nation," and "chiefs who are peers of their tribes and recognized by all," but they were first and foremost "my Indian friends."107 In reciprocation, they ultimately entrusted her with the recording of over five hundred songs, and "open-ended conversations ... amounting to several hundred pages of information." 108

Notwithstanding this huge repository of West Coast First Nations voices singing and discussing their own musics, I would submit that Halpern's legacy extends as well to her personal style of working with people, her at times innovative scholarship and her independently postmodern-ish style of writingno mean feats for the first practicing scholar in Canada to hold a Ph.D. in musicology and a woman who lived a life "like a professor's except that she held no university job."109

106 Halpern, "Music of the B.C. Northwest Coast Indians," in Proceedings of the Centennial Workshop on Ethnomusicology, 1:23.

107 Halpern, "Nootka Music: Reply to Goodman," 294-95.

108Halpern, Kwakiutl Indian Music of the Pacific Northwest, 2.

109 Cameron, "The Collector: And the Music That Nearly Died Lives On," 20. 


\section{Appendix: Ida Halpern's Writings}

Franz Schubert in der zeitgenössischen Kritik. Unpublished Ph.D. diss. Vienna: University of Vienna, 1938.

"What is Modern Music?" Pacific Northwest Library Association Quarterly 11, no. 2 (January 1947): 70-75. [A paper read at a meeting of the Northwest Chapter, Music Library Association, held in conjunction with the PNLA Conference in Vancouver on 6 September 1946.]

"Bella Bella and Kwakiutl Songs." In World Library of Folk and Primitive Music. Volume VIII: Canada. Compiled and edited by Marius Barbeau and Alan Lomax. Columbia Record no. SL 211. New York: Columbia Records, 1953. [Thirty-nine songs on this single long-playing album, with three songs collected and annotated (140 words) by Halpern.]

"Kwa-Kiutl Indian Music." Journal of the International Folk Music Council 14 (January 1962): 159-60. [A summary of a paper presented at the 14th Annual Conference of the IFMC in Sainte-Foy, Quebec, on 1 September 1961.]

Indian Music of the Pacific Northwest Coast. Folkways Records Album no. FE 4523. Double-LP, 36 pp. New York: Folkways Records \& Services, 1967.

"Music of the BC Northwest Coast Indians." In Proceedings of the Centennial Workshop on Ethnomusicology, edited by Peter Crossley-Holland, vol. 1, [Workshop Proceedings], 23-42, and vol. 2, The Complete Discussions, 20-34, 79. Victoria: Queen's Printer (Government of the Province of British Columbia), 1968. [Vol. 1 reprinted (2nd ed.) in 1970 by Vancouver: Center for Continuing Education, University of British Columbia, and revised (3rd ed.) in 1975 by Victoria: Aural History, Provincial Archives of British Columbia.]

Nootka Indian Music of the Pacific North West Coast. Folkways Records Album no. FE 4524. Double-LP, 16 pp. New York: Folkways Records \& Services, 1974.

"On the Interpretation of 'Meaningless-Nonsensical Syllables' in the Music of the Pacific Northwest Indians." Ethnomusicology 20, no. 2 (1976): 253-71.

Book Review of Pamela Amoss, Coast Salish Spirit Dancing: The Survival of an Ancestral Religion (Seattle: University of Washington Press, 1978), in Ethnomusicology 24, no.2 (1980): 287-89.

"Indians" and "Pacific Northwest Coast." In Encyclopedia of Music in Canada, edited by Helmut Kallman, Gilles Potvin, and Kenneth Winters, 448-51. Toronto: University of Toronto Press, 1981.

Kwakiutl Indian Music of the Pacific Northwest. Folkways Records Album no. FE 4122. Double-LP, 50 pp. New York: Folkways Records \& Services, 1981.

"Nootka Music: Reply to Goodman." Ethnomusicology 25, no. 2 (1981): 294-97.

"Letter to the Editor." Ethnomusicology 27, no. 1 (1983): 171-73. [Halpern's response to the journal's edited publication of her rebuttal to Linda Goodman's review of Halpern's Nootka album, in issue 25, no. 2 (1981): 294-97]

Haida Indian Music of the Pacific Northwest. Folkways Records Album no. FE 4119. Double-LP, 14 pp. New York: Folkways Records \& Services, 1986.

““... a very agreeable harmony.' Impressions of Nootkan Music." Sound Heritage 7, no. 1 (1978): 63-70 [with David Duke]. 


\begin{abstract}
The work of Ida Halpern (1910-87), one of Canada's first musicologists and a pioneer ethnomusicologist, has been largely ignored. This essay illuminates her most important contribution to the musical development of this country: the documentation of Native musics. Halpern devoted some four decades to recording and analyzing over five hundred songs of the Kwakwaka'wakw, the Nuuchahnulth, the Haida, the Nuxalk, and the Coast Salish First Nations of British Columbia-a truly remarkable achievement considering that a large part of her fieldwork was conducted during a period when it was illegal for Native cultures to be celebrated, much less preserved. The author discusses the strengths and weaknesses of her methodology as well as some factors affecting the reception of her work by academic peers and by the communities she worked with. While Halpern did not always thoroughly investigate context, she endeavoured to write heteroglossically and to invent a theory that accounted for the music of these songs.
\end{abstract}

